\title{
Seismic risk management of piles in liquefiable soils stabilised with cementation or lattice structures
}

Rohollah Rostami MSC

PhD Researcher, Glasgow Caledonian University, Glasgow, UK (corresponding author: rrosta200@caledonian.ac.uk) (Orcid:0000-0003-3477-9182)

Subhamoy Bhattacharya PhD

Professor and Chair in Geomechanics, University of Surrey, Guildford, UK
Nicholas Hytiris PhD

Senior Lecturer, Glasgow Caledonian University, Glasgow, UK

Slobodan B. Mickovski PhD

Professor, Glasgow Caledonian University, Glasgow, UK

Liquefaction is an important seismic hazard that can cause extensive damage and high economic impact during earthquakes. Despite the extensive research, methodologies and approaches for managing liquefaction for pilesupported structures, failures of structures due to liquefaction have continued to occur to this day. The main aim of this paper is to develop a simplified methodology for reducing potential structural damage of structures founded in soils susceptible to liquefaction. In order to implement a successful remediation technique, the current methods for pile failure in liquefiable soils and remediation schemes of earthquake-induced liquefaction are critically reviewed and discussed. Cementation and lattice structure techniques for reducing liquefaction hazard are proposed, while numerical analysis for unimproved and stabilised soil profiles using the finite-element method is carried out to simulate the analysis of both stabilisation techniques. The results showed that both techniques are effective and economically viable for reduction or avoidance of potential structural damage caused by liquefied soil and can be used in isolation or in combination, depending on the ground profile and pile type.

\section{Notation}

$c_{\mathrm{u}}$

D

$D_{\mathrm{L}}$

EI

$E_{\mathrm{s}}$

$f_{\text {c }}^{\prime}$

$f_{y}$

G

$H_{\mathrm{c}}$

K

k

$P_{\text {dynamic }}$

$\alpha$

$\gamma$

$\varepsilon_{\mathrm{c}}$

$\sigma_{\mathrm{y}}$

$v$

$\Phi$

$\varnothing$

\section{Introduction}

Damaging effects in pile-supported structures due to liquefiable soils were extensively observed during and after earthquakes in the past (Bhattacharya, 2006; Bhattacharya et al., 2011; Lombardi and Bhattacharya, 2012; Tokimatsu and Asaka, 1998), which put the remediation of earthquake-induced liquefaction in the focus of geotechnical earthquake engineering practice. Liquefaction has been shown to occur when, during seismic vibration, the pore water pressure in the usually loosely deposited sandy soil layers increases rapidly and sufficiently, which may lead to a decrease in the effective stress in the soil to zero (Booth, 1994). Although through evaluation of the seismic risk and subsequent management the existing piled foundations usually achieve the desired level of safety, failures of structures due to liquefaction still occur. Therefore, there is an urgent need to understand better and clarify this complex phenomenon, as well as to identify how liquefaction affects piles.

During earthquakes, the response of pile-supported structures to liquefiable soils depends on the stiffness of the pile foundation, the response of the soil surrounding the pile and the soil-pile interaction effects (NEHRP, 2012). The interaction effects include the inertial loading exerted by the superstructure and the kinematic loading induced by the soil surrounding the pile (Figure 1).

Before the earthquake, the axial load on the piles can be estimated based on static equilibrium. At the start of the seismic vibration and before the excess pore water pressure build-up, this axial compressive load may increase/decrease further due to the inertial effect of the superstructure (due to oscillation of superstructure) and the kinematic effects of the soil flow past the foundation (due to ground movement). This change in loading can be transient (during the vibration, due to the dynamic effects of the soil mass) and residual (after the vibration, due to soil flow, often known as 'lateral spreading' (Bhattacharya and Madabhushi, 2008)). 

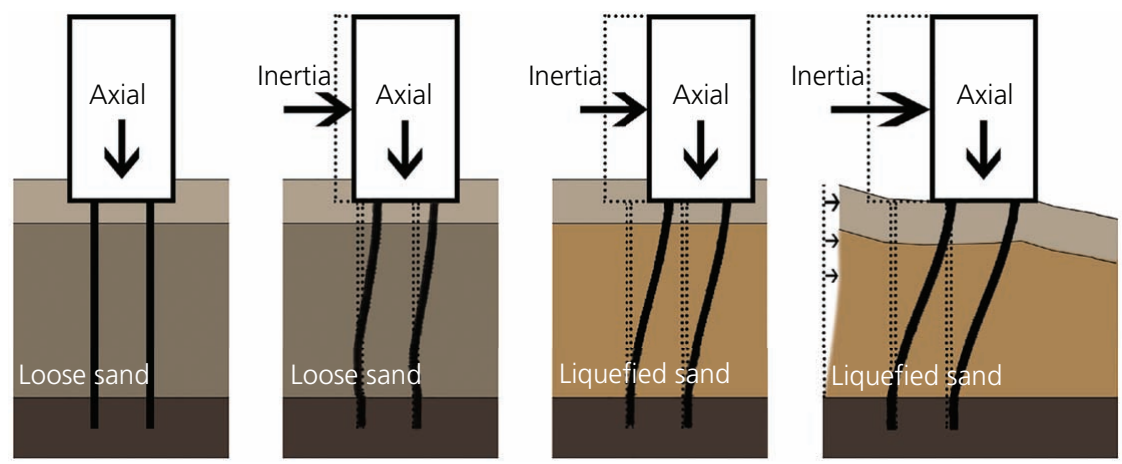

Figure 1. Different stages of loading and failure mechanism of pile during earthquake (adapted from Bhattacharya (2014))

However, at this stage, with pore water pressure built up (at full liquefaction, the excess pore water pressures reach the overburden vertical effective stress), the soil loses its strength and stiffness and the pile acts as an unsupported column over the liquefied depth (Lombardi and Bhattacharya, 2014). Most of the efforts have been made to improve greatly the understanding of pile failure mechanism due to liquefaction. However, further research is required to develop insight into the effects of liquefaction triggering on the seismic response of structures and soil stiffness.

It is widely accepted that the impact of geotechnical hazards is the main contributor in the damage to structures during earthquakes (e.g. Kramer et al., 2014). The assessment of geotechnical hazards is, therefore, essential for quantification of the seismic safety and liquefaction mitigation of these structures. Various ground improvement techniques are used for remediation of piled foundations in liquefiable soils including densification, preferential drainage path provision, soil reinforcement, removal and replacement of the liquefiable soils with competent soils and so on (Mitchell, 2008; Rayamajhi et al., 2015). However, the behaviour of piled foundations stabilised with these techniques has rarely been modelled or quantified in the past, which has affected the acceptance of these techniques in geotechnical engineering practice and the overall seismic risk management (SRM) approach to piles in liquefiable soils.

The main aim of this study is to develop a novel approach for SRM by providing a methodology for reducing potential structural damage of pile-supported structures founded in soils susceptible to liquefaction. In order to investigate the feasibility of a successful remediation technique, the current methods for pile failure in liquefiable soils and remediation schemes of earthquake-induced liquefaction will be critically reviewed and discussed. Two viable methods to reduce the liquefaction hazard (cementation and lattice structure techniques) will be proposed and numerically simulated using the finite-element method (FEM) in order to establish areas for application of the proposed techniques and methodology.

\section{Methodology}

In this study, the authors propose a methodology where the SRM for mitigating liquefaction is evaluated by comparing consistent measures of seismic loading that have caused pile failure and liquefaction resistance (Kramer, 2008). Therefore, both the current understanding of pile failure in liquefiable soils and the remediation schemes will have to be investigated and understood (Figure 2). Once these are critically reviewed, the SRM for mitigating the risks on pile-supported structures in liquefiable soils by using

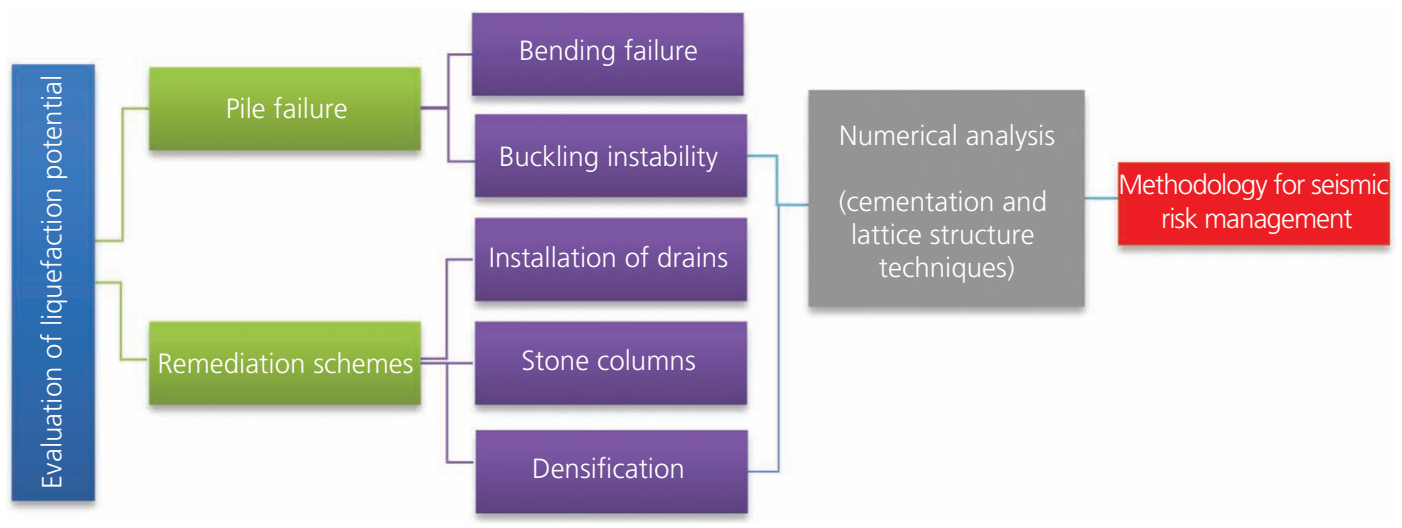

Figure 2. Schematic illustration of the methodology 
cementation and lattice structure improvement techniques will be proposed and demonstrated through numerical simulation. The numerical modelling using the FEM software Abaqus will be carried out to analyse both unimproved and stabilised soil profiles. The results of the analysis and simulation will be then used to focus on the behaviour of the improvement (stabilisation) techniques during earthquake as well as on their effects on the soil and structures. Additionally, the proposed methodology will examine and determine the ability and mitigation potential of the proposed techniques in the light of ground deformations for piles. Finally, the findings of the simulations and analyses will be used to perform SRM by developing a liquefaction remediation strategy.

\section{Current understanding of pile failure due to seismic liquefaction}

A number of research studies have been carried out in the past to predict the response of soil-foundation-structure systems in order to avoid collapse and decrease the damage levels (e.g. Bhattacharya and Goda, 2013; Bhattacharya et al., 2014; Dammala et al., 2017; Krishna et al., 2014). Liquefaction hazard evaluation is generally concerned with two different mechanisms of pile failure: failures due to bending (flexural) or buckling of the pile (Bhattacharya et al., 2004; Dash et al., 2010; Lombardi and Bhattacharya, 2014, 2016; Rostami et al., 2017). Bending failure (flexural failure) occurs when the soil surrounding the piles liquefies and loses much of its stiffness, causing the piles to act as unsupported slender columns, while buckling failure occurs when piles act as beam columns under both axial and lateral loading. Evaluating the potential for initiation of liquefaction (i.e. liquefaction potential) involves comparing the anticipated level of loading applied to the structure as a result of a seismic vibration at a particular site with the liquefaction resistance of the soil at the same site.

In practice, different design procedures have been used for the seismic design of pile-supported structures. The Japanese highway code of practice (JRA, 2002), for example, advises practising engineers to consider both the loading conditions mentioned previously. However, it suggests a separate bending failure (flexural failure) check for the effects of kinematic and inertial forces. Similarly, BS EN 1998-1 (Eurocode 8) (BSI, 2005a) advises pile design against bending due to inertial and kinematic forces arising from the deformation of the surrounding soil. In the event of liquefaction, Eurocode 8 also suggests that 'the side resistance of soil layers that are susceptible to liquefaction or to substantial strength degradation shall be ignored' (BSI, 2005a: p. 26). The National Earthquake Hazards Reduction Program (NEHRP, 2000), on the other hand, focuses on the bending strength of the piles by treating them as laterally loaded beams and assuming that the lateral load due to inertia and soil movement causes bending failure. Based on these guidelines, for this study, the pile is modelled as a beamcolumn element carrying both axial and seismic loads.

\section{Current remediation schemes}

Piled foundations of existing buildings are often difficult to access for retrofitting, and, in addition, any procedure must ensure that the superstructure is not damaged during remediation (Mitrani and Madabhushi, 2013). Remediation of existing structures founded in liquefiable soils is usually carried out using methods such as installation of drains (Brennan and Madabhushi, 2002), stone columns (Asgari et al., 2013; Gniel and Bouazza, 2009; Lo et al., 2010; Tang et al., 2015) and densification (e.g. using deep dynamic compaction, vibro compaction and compaction piles) (Adalier et al., 2003; Baez, 1995; Coelho et al., 2007; Mitchell, 2008). Densification methods have been widely studied because these techniques are relatively simple and practical and the resulting remediation success can be easily verified by using in situ penetration techniques (Charlie et al., 1992; Elias et al., 2006; Mitchell and Solymar, 1984). For example, the effects of sand layers of varying density, thickness and extent of the behaviour of a bridge abutment have been investigated by Balakrishnan and Kutter (1999) and Kutter et al. (2004). However, Rayamajhi et al. $(2014,2015)$ reported that the densification and drainage techniques of improvement are often ineffective, while the soil-cement columns were relatively ineffective in reducing the potential for liquefaction triggering in saturated silty soils.

The cementation and lattice structure techniques (e.g. grouting injection, deep soil mixing) for soil improvement structures have been studied in the past (e.g. Funahara et al., 2012; Kitazume and Takahashi, 2010; Namikawa et al., 2007; Nguyen et al., 2012, 2013; Tokimatsu et al., 1996; Yamauchi et al., 2017) and were shown to stabilise liquefiable soils at reduced installation costs effectively.

\section{Numerical modelling}

In the present study, a numerical method was used to investigate the stabilising mechanisms of cementation and lattice structure techniques in liquefiable soils as an extension of the previous research conducted by authors (Rostami et al., 2017) and discussion on the verification of numerical modelling procedures was well explained in a previous paper. Three-dimensional (3D) non-linear dynamic analyses were performed for a piled foundation on a liquefiable soil layer in original (unimproved) and stabilised (cementation and lattice structure techniques) soil profiles. These analyses were carried out in Abaqus and included modelling of a single pile as a beam-column element carrying both axial and seismic loading, within a liquefiable soil which is stabilised using the two chosen techniques. The observed deformation of the pile affected by soil liquefaction was used to demonstrate the pile capacity and predict the thickness of the stabilised soil layer that would be affected in the seismic event. The results of these analyses provide the required thickness and the properties of the zone of liquefiable soils requiring treatment.

\section{Overview of models}

Figure 3(a) shows the extent of a 3D ground model comprising three soil layers. The liquefiable soil was modelled in between two layers of non-liquefiable soil (Figure 3(b)), and a reinforced-concrete pile with a fixed head was modelled to span the three soil layers with varying properties (thickness, type, articulation). Due to axial 
Seismic risk management of piles in

liquefiable soils stabilised with

cementation or lattice structures

Rostami, Bhattacharya, Hytiris and Mickovski

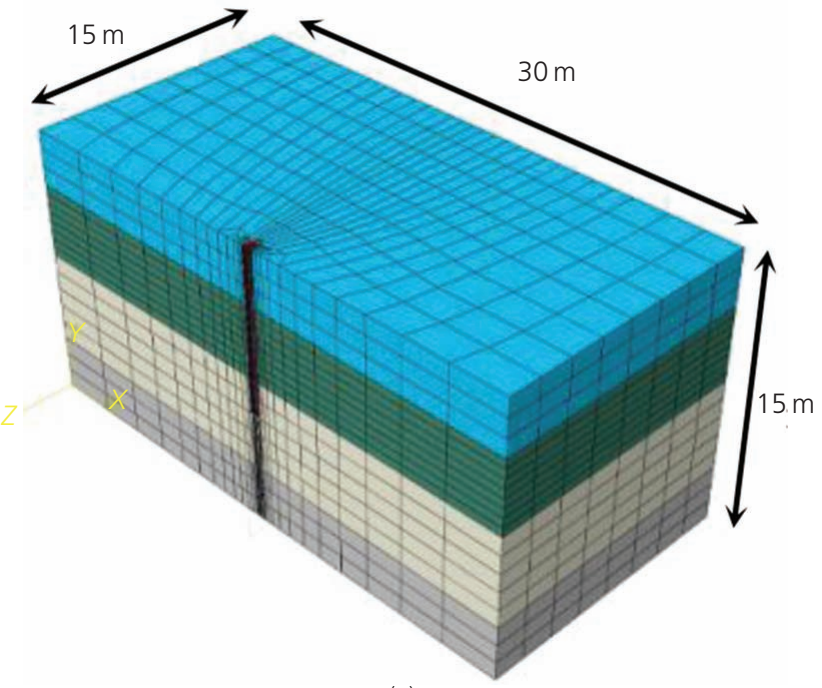

(a)



(b)

Figure 3. (a) The 3D numerical model; (b) details of the pile and model

symmetry, only half of the pile and surrounding soil were modelled for the original and stabilised (a cement-injected layer in lieu of the liquefiable layer soil stratum) soil profile. Additionally, cases of pile without and with the cement-injected layer were modelled (Figure 4).

The different thicknesses of liquefiable soil profiles (1, 3 and $9 \mathrm{~m})$ surrounding the pile were considered to be wide enough to identify the effectiveness of the free-field kinematic demand imposed on the soil system. The full model is shown in Figure 5, which was used for lattice structure technique evaluation.

\section{Modelling the soil-pile system}

For the FEM to simulate the pile-soil interaction effectively, it was important to define appropriately the interaction between the pile and the soil near the solid-to-liquefied layer interface. To model the interaction between the soils and pile, the 'surface-tosurface' contact method (a.k.a. 'master-slave' surface) was used, where the more deformable and more rigid surfaces are defined as the 'slave' and 'master' surfaces, respectively (Dassault Systèmes Simulia, 2012).

The non-linear $p-y$ curves of the liquefied soil used in the modelling of the soil-pile-structure interaction were based on the beam on elastic foundation approach (Hetényi, 1946). The $p-y$ curves have been used to model the reaction of the foundation with consideration of inertial effects and seismic soil-pile interaction. In this study, the non-linear spring stiffness $(p-y$ curves) of the liquefied soil is used to evaluate soil-pile interaction analysis and performed pile bending moments.

To evaluate the soil-pile interaction of the liquefied soil, analysis is normally performed in terms of shear forces and pile bending moments (McGann et al., 2012). However, the pile bending moments could not be directly obtained from the Abaqus output as the pile was modelled as a solid element. This restriction was overcome by adding a very flexible beam element along the pile (Banerjee and Shirole, 2014).

The dynamic load model requires boundary conditions that offer support to the elements while restricting unnecessary motions (Dassault Systèmes Simulia, 2012). For dynamic cases, the ability of the infinite elements to transmit energy out of the FE mesh, without trapping or reflecting it, is optimised by making the boundary (same material for each layer without damping) between meshes as close as possible to orthogonal in the direction from which the waves will impinge on the boundary (i.e. close to a free surface, where Rayleigh or Love waves may be significant; Figure 6) (Dassault Systèmes Simulia, 2012).

During earthquakes, the excess pore water pressure in loose, saturated soils increases, thus reducing the effective stress in the layer and, subsequently, significantly decreasing the shear strength. As a result of the pore water pressure build-up, the compressibility of the layer cannot change drastically (McGann et al., 2012) so the soil bulk modulus, $K$, is assumed to remain constant throughout the soil mass and the Poisson's ratio of liquefiable soils is assumed as $v=0.485$ (McGann et al., 2012). Additionally, the Mohr-Coulomb failure criterion is used to simulate the soils behaviour (Helwany, 2007), while the hypoelastic model in Abaqus was used to simulate non-linearity below the yield envelope (Banerjee and Shirole, 2014).

The seismic loading was applied at bedrock level (assumed below the three soil layers) in the horizontal direction in the form of an acceleration time history. The input motion of harmonic excitation consisted of waves of unit amplitude and different frequencies for the first $8 \mathrm{~s}$ of the El Centro earthquake record scaled to $0 \cdot 30 \mathrm{~g}$ and used as the base input acceleration (Figure 7(a)). However, the input motion was applied at $0 \cdot 15 \mathrm{~g}$ due to the larger values of initial effective stress at the lower layers (Rahmani and Pak, 2012). The axial load of $1100 \mathrm{kN}$ (Figure 7(b)) was applied throughout the seismic loading to simulate the increasing axial load due to equilibrium satisfied within the soil layers.

\section{Modelling the pile and lattice structure}

The piles in this study include one deep foundation reinforcedconcrete pile (Figure 4) modelled using beam-column elements as elastic materials, reflecting a typical precast pile used in construction $\left(0 \cdot 16 \mathrm{~m}^{2}\right.$ section, lengths of 9 and $\left.12 \mathrm{~m}\right)$. 




(a)

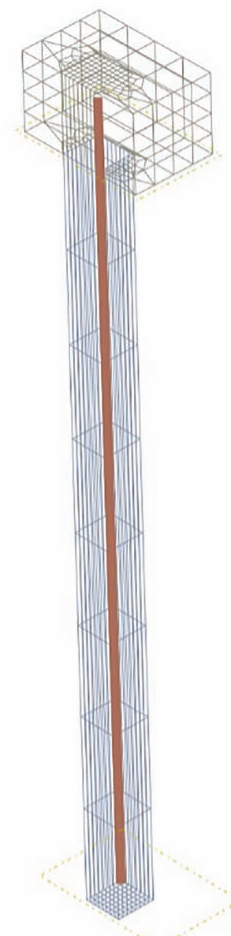

(b)

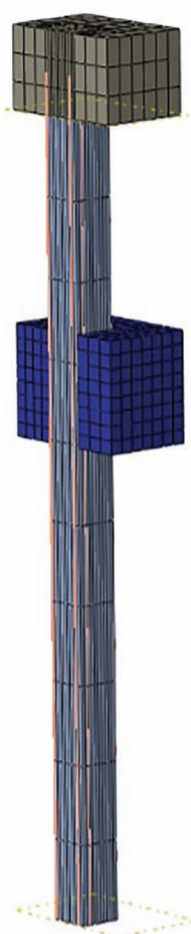

(c)

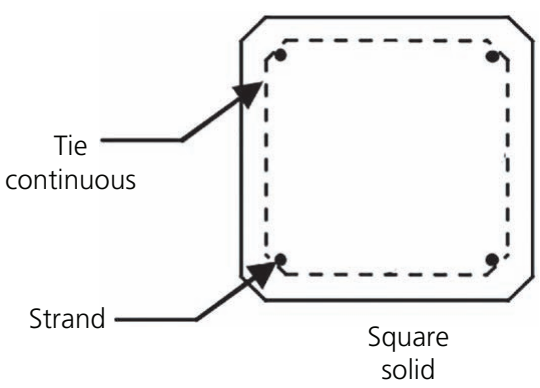

(d)

Figure 4. (a) Details of the pile; (b) the flexible beam element along the pile; (c) pile with cement injected (stabilised) layer; (d) crosssections of the piles

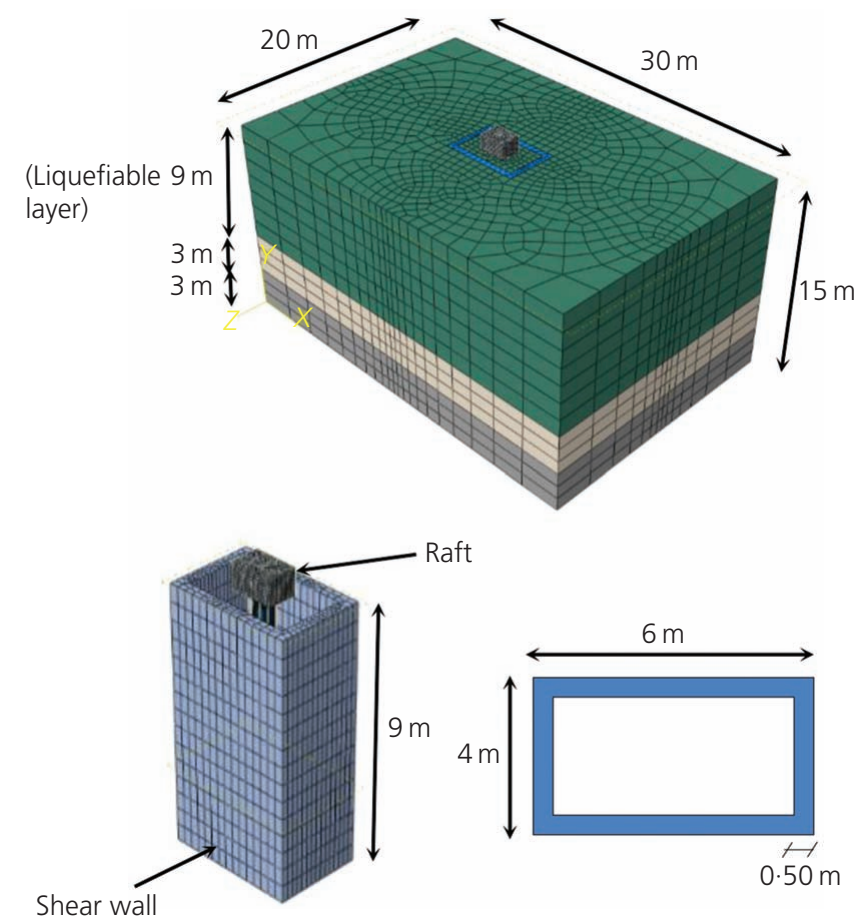

Figure 5. Details of the lattice structure and model
In this study, a 3D model of a lattice structure surrounding the pile (Figure 5) is used as a representative of lattice structure used to remediate against the potential effects of earthquake-induced liquefaction phenomenon (Nguyen et al., 2013). The lattice structure walls were modelled as a shear box, which can provide additional shear stiffness and strength for sites to withstand liquefaction (Nguyen et al., 2013).

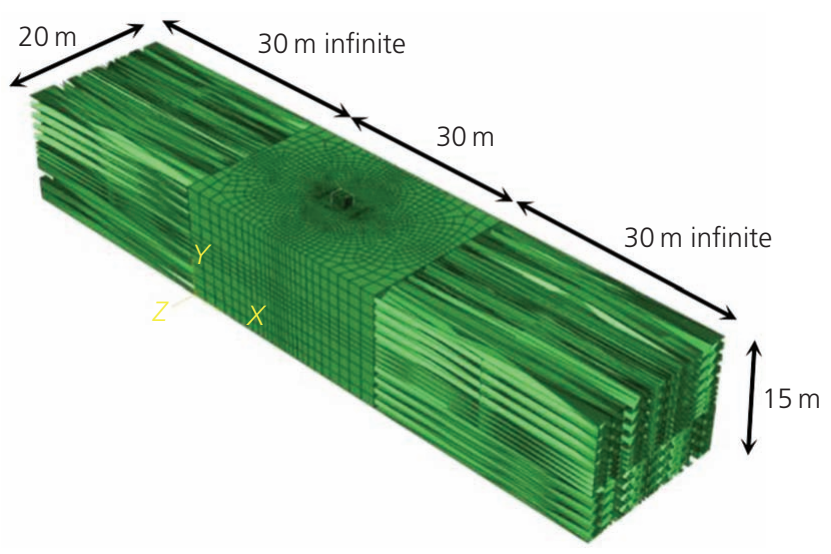

Figure 6. The infinite elements for transmitting energy out of the FE mesh 
Seismic risk management of piles in

liquefiable soils stabilised with

cementation or lattice structures

Rostami, Bhattacharya, Hytiris and Mickovski

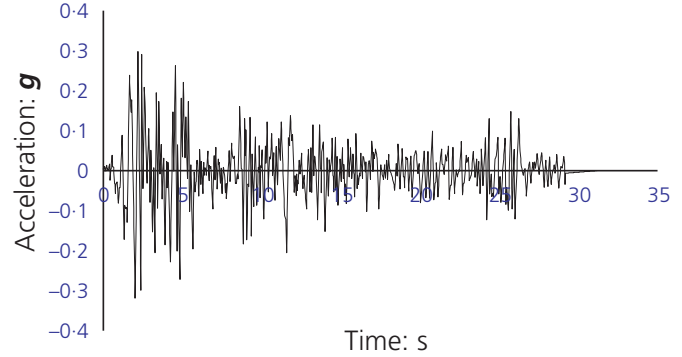

(a)

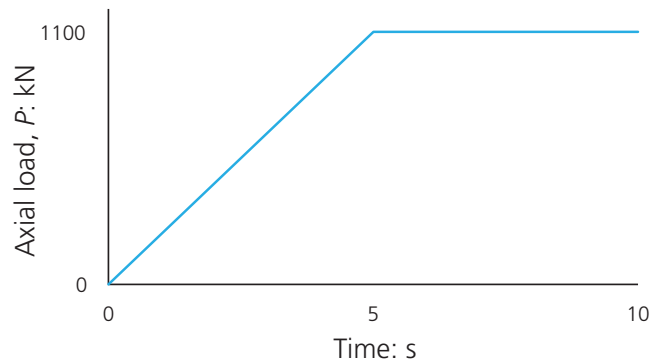

(b)

Figure 7. Seismic loading for this study: (a) acceleration record of the El Centro (1940) earthquake; (b) increase in axial load

The properties of piles, raft, cement injection and lattice structure are given in Table 1.

\section{Modelling the soil}

Three typical soils were modelled in three dimensions, surrounding the pile, varying the thicknesses of liquefiable layer between the two non-liquefied layers and material properties to explore the effects of liquefaction on the pile. Appropriate values for the soil parameters were chosen from previous case histories
(Sarkar et al., 2014) to ensure valid results. The soil parameters selected for the FE model are summarised in Table 2.

\section{Analysis and results}

In order to implement a successful remediation technique for the SRM of pile-supported structures in liquefiable soils, a parametric study has been carried out on three different soil profiles, varying the thickness of liquefiable soil. To obtain results, 12 soil profiles for each of three different thicknesses of liquefiable soil profiles $(1,3$ and $9 \mathrm{~m})$ and the unimproved and stabilised soil for both cementation and lattice structure techniques were modelled.

\section{Analysis of 3D FEM}

As expected, the effect of the remediation technique was dependent on the respective material properties, thickness of cement layer, input wave and the surrounding soil. The behaviour at each incremental point along the pile length was calculated and plotted. An example of deformed shape of the systems and the interaction between the soil and the pile are shown in Figure 8.

From the deformed shape of the system, it can be observed that the imposed displacement profile triggers bending in the pile. It also shows that the non-liquefiable layers of soil begin to displace laterally with respect to the liquefiable layer. However, the pile provides resistance to this motion as the upper portion is pushed along with the flow of soil. This behaviour is illustrated in the lateral stress distribution curve (Figure 9) which is shown alongside the maximum bending moment.

\section{Cement injection improvement}

Figure 9 illustrates the maximum bending moment developing along the length of piles embedded in soil layers without and with cement injection layer. It can be seen that the imposed displacement induces

Table 1. Properties of piles, raft, cement injection and lattice structure models

\begin{tabular}{|c|c|c|c|c|c|c|}
\hline Item description & Poisson's ratio & Modulus of elasticity: $\times 10^{6} \mathrm{kN} / \mathrm{m}^{2}$ & Unit weight: $\mathrm{kN} / \mathrm{m}^{3}$ & $\sigma_{\mathrm{y}}: \mathrm{MPa}$ & $f_{c}^{\prime}: k P a$ & $\mathcal{E}_{\mathrm{c}}$ \\
\hline $9 \mathrm{~m}$ pile & 0.15 & 30 & $24 \cdot 0$ & 1860 & 44816 & 0.03 \\
\hline 12 pile & $0 \cdot 15$ & 30 & $24 \cdot 0$ & 1860 & 44816 & 0.03 \\
\hline Steel material & 0.30 & 200 & 78.5 & & & \\
\hline Cement injection layer & 0.35 & 1.5 & 15 & & & \\
\hline Lattice structure & 0.35 & $1 \cdot 5$ & 15 & & & \\
\hline
\end{tabular}

$f_{c}^{\prime}$ compressive strength; $\varepsilon_{\mathrm{c}}$ concrete strain; $\sigma_{\mathrm{y}}$, yield strength

Table 2. Soil parameters

\begin{tabular}{|c|c|c|c|c|c|c|c|c|}
\hline & Layer & Basic description & $\gamma: \mathrm{kN} / \mathrm{m}^{3}$ & $\begin{array}{l}\text { Cohesion, } \\
c_{\mathrm{u}}: \mathrm{kPa}\end{array}$ & $\begin{array}{c}\text { Friction angle, } \\
\Phi:^{\circ}\end{array}$ & $v$ & $\begin{array}{c}\text { Shear modulus } \\
\text { G: } \mathrm{kPa}\end{array}$ & $K: \mathrm{kPa}$ \\
\hline \multirow{6}{*}{$\begin{array}{l}\text { Liquefiable } \\
\text { zone }\end{array}$} & 1 & Soft silty clay & $19 \cdot 1$ & $40 \cdot 0$ & - & 0.350 & 9260 & 27777.8 \\
\hline & $\|$ & Soft clayey silt & $18 \cdot 2$ & $23 \cdot 0$ & - & 0.350 & 9260 & 27777.8 \\
\hline & III & Loose sandy silt & $18 \cdot 0$ & - & $28 \cdot 0$ & 0.485 & 824 & 27777.8 \\
\hline & IV & $\begin{array}{l}\text { Medium dense silty } \\
\text { sand }\end{array}$ & $19 \cdot 0$ & - & $30 \cdot 0$ & 0.485 & 824 & $27777 \cdot 8$ \\
\hline & V & Stiff clayey silt & $18 \cdot 4$ & $49 \cdot 0$ & - & 0.485 & 824 & $27777 \cdot 8$ \\
\hline & $\mathrm{VI}$ & $\begin{array}{l}\text { Medium dense silty } \\
\text { sand }\end{array}$ & $19 \cdot 0$ & - & $32 \cdot 0$ & 0.350 & 9260 & $27777 \cdot 8$ \\
\hline
\end{tabular}




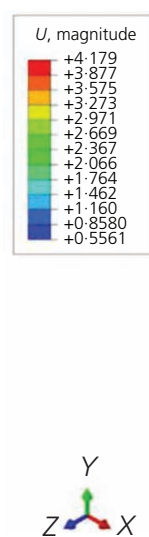

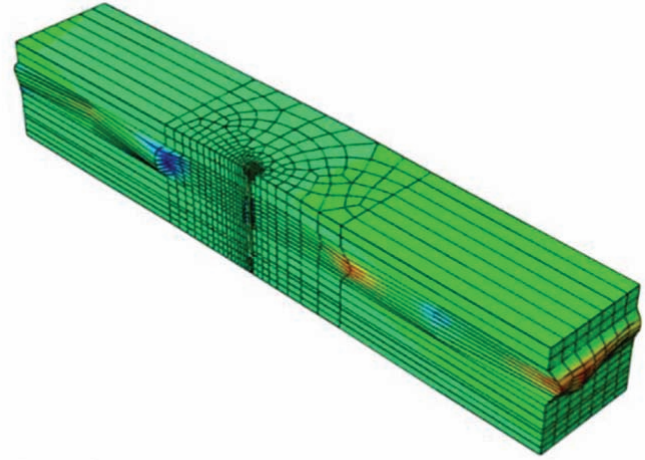

Abaqus/standard 6.14-1

(a)



(b)

Figure 8. (a) Deformed shape of model of unimproved soil with $3 \mathrm{~m}$ thickness of liquefiable soil; (b) pile deformation

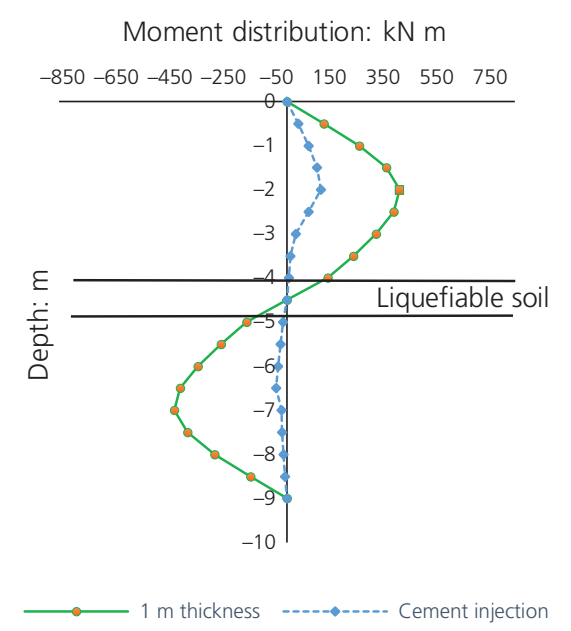

(a)

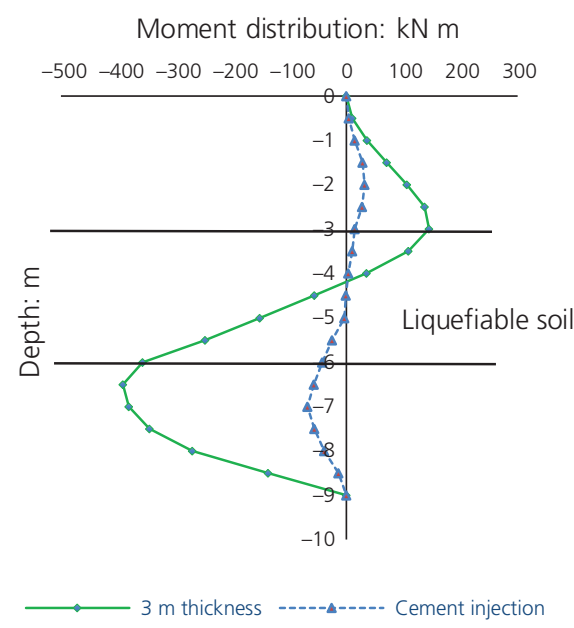

(b)

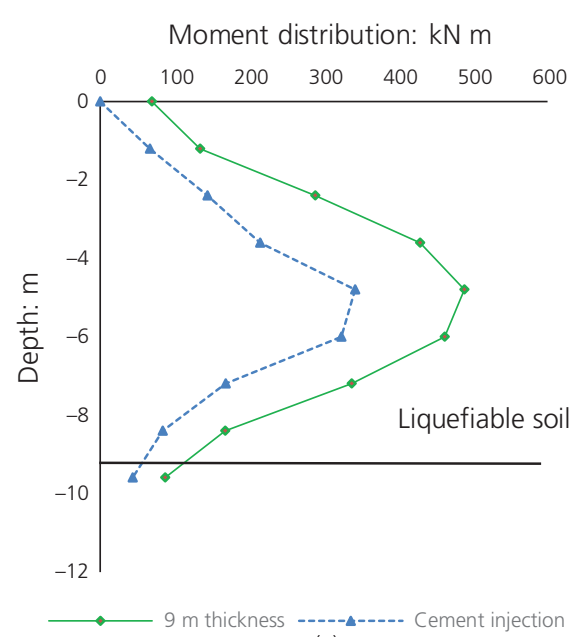

(c)

Figure 9. The bending moment without cement injection and with cement injection: (a) $1 \mathrm{~m}$, (b) $3 \mathrm{~m}$ and (c) $9 \mathrm{~m}$ thicknesses of liquefiable soil

bending in the pile. It can also be observed that that the volume of soil improvement could be reduced by $90 \%$ for $1.0 \mathrm{~m}$ of liquefiable layer thickness and $70 \%$ for $3 \mathrm{~m}$ thickness of liquefiable soil. However, the $9 \mathrm{~m}$ thick liquefiable soil layer can provide $30 \%$ resistance to liquefaction and this stability is not satisfied. It can be explained through the interaction of different factors, that decreasing density and stability. The large thickness of liquefiable soil in touch with pile and the lateral stress distribution of the nature of ground motions and containing pore pressure generation put the pile at the maximum of bending and increasing shear stress. It is found that for the range of parameters used in this study, the bending moment reduction using cement injection across one-third of liquefiable soil thickness may be sufficient to prevent liquefaction (Figure 9(b)), and this solution could be considered for thin liquefiable layers with a thickness of less than one-third of pile length.

Therefore, it would be prudent for this method to be used as a secondary rather than primary mechanism for ground improvement in liquefiable soil with liquefiable layers with thickness of more than one-third of pile length, although cement injection may help to prevent liquefaction triggering in stabilised thin liquefiable soil.

\section{Lattice improvement}

Figure 10 shows the bending moment reduction achieved by using lattice structure. Based on the numerical analyses, a new simplified design method was proposed, which better quantifies the level of bending moment reduction in the improved soil. It can be seen that in the improved case, the bending moment is reduced due to dilation of the lattice structure, such that the decrease in lateral soil movement. The results in Figures 10(a)-10(c)) show that the lattice structure mechanism could be sufficient for prevention of liquefaction triggering and ground improvement in liquefiable soil. As illustrated in Figure 10(a), this could be improved by $90 \%$ for $3 \mathrm{~m}$. However, for thicker liquefiable soil layers, the lattice walls would tend to be more flexible and may offer improvements of as 
Geotechnical Research

Volume 6 Issue GR2
Seismic risk management of piles in

liquefiable soils stabilised with

cementation or lattice structures

Rostami, Bhattacharya, Hytiris and Mickovski
Moment distribution: $\mathrm{kN} m$

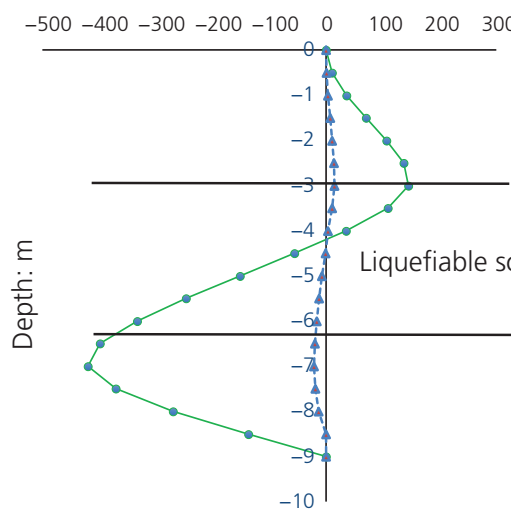

- $3 \mathrm{~m}$ thickness -.---ـ-.-- Lattice structure

(a)

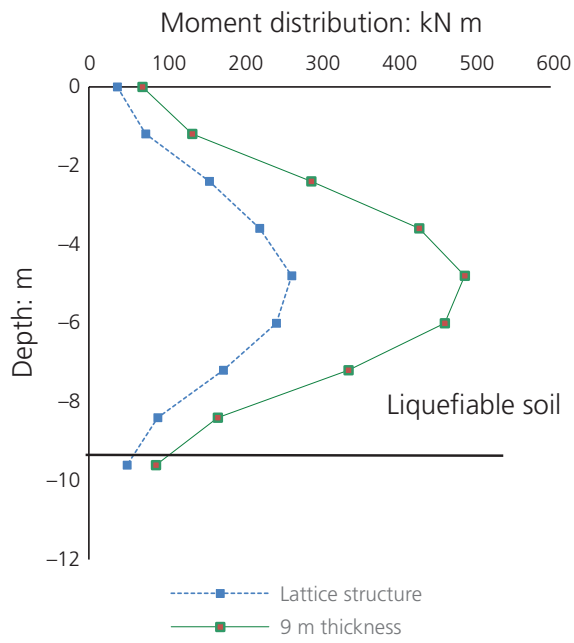

(b)

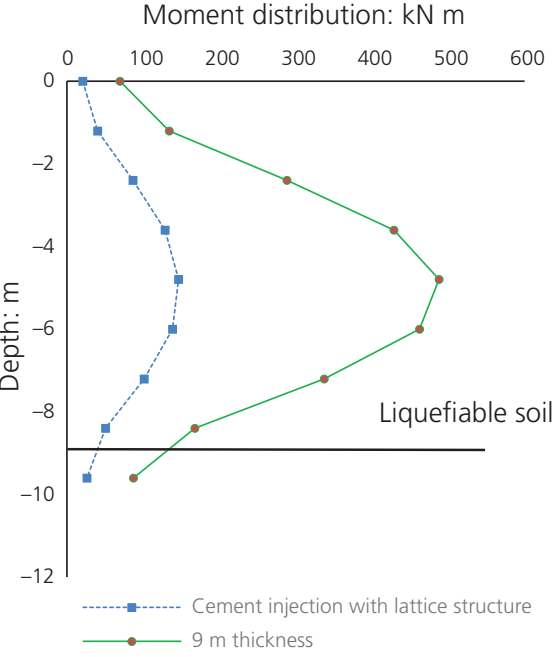

(c)

Figure 10. The bending moment with and without lattice structure: (a) $3 \mathrm{~m}$ thickness; (b) $9 \mathrm{~m}$ thickness; (c) $9 \mathrm{~m}$ thickness with both cement injection and lattice structure

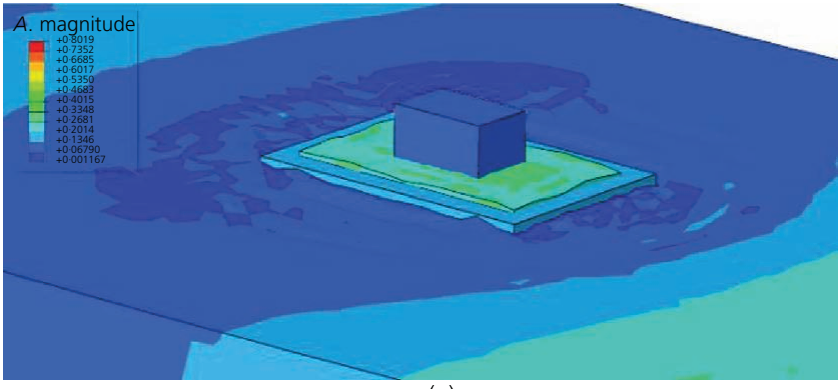

(a)

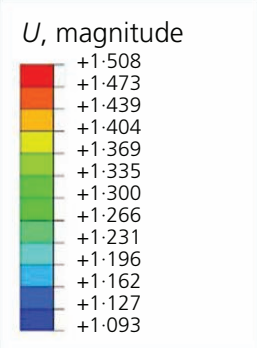<smiles>[Y]C([Y])C([Y])[Y]</smiles>

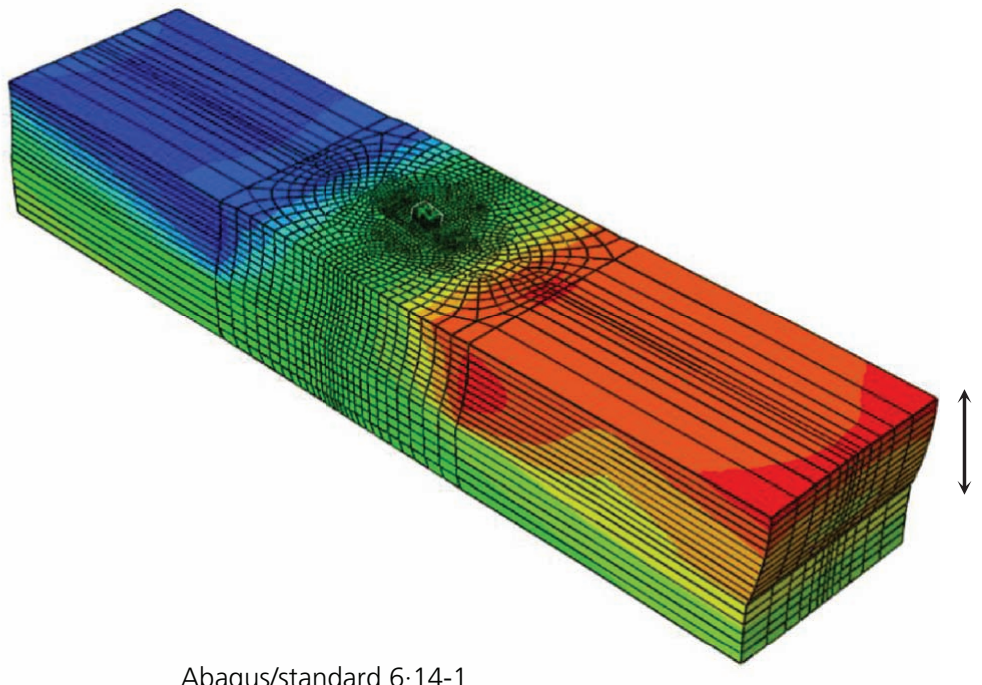

9 m liquefiable layer

Figure 11. (a) The deformed shape around the shear wall; (b) deformed shape of model $9 \mathrm{~m}$ thickness of liquefiable layer with lattice structure 
little as 50\% (Figure 10(b)). In such conditions, it may be better to consider lattice in conjunction with cement injection for ground improvement in liquefiable soil by $70 \%$ (Figure 10(c)). An example of the deformed shape of a lattice structure used for remediation of liquefiable soil is illustrated in Figures 11(a) and 11(b) sequentially. Figure 11(a) shows that the dynamic amplitude leads to a change in effective stress of the soil and increasing shear stress with time. It can also be observed that a shear wall can stabilise the effective stress path and provide some additional stiffness of the soil under these conditions.

Figure 12 shows the excess pore water pressure generated near a pile at $5 \mathrm{~m}$ below the soil surface for the case of $1 \mathrm{~m}$ cement injection improvement and 3 and $9 \mathrm{~m}$ of lattice structure model during and after earthquakes, respectively. It can be seen that lower levels of the excess pore water pressure (blue colour) were generated in the stabilised soils. As illustrated (Figure 12), limiting the excess pore pressure for all cases and the ground improvement can prevent and protect the pile against liquefaction.
However, the case of $9 \mathrm{~m}$ thick liquefiable soil shows that the excess pore pressure decreases slightly. This excess pore pressure behaviour can be understood by hydraulic gradients that drive pore water flow both during and after earthquake shaking (Kramer, 2008). In this case, the flow might migrate upwards, even under the structure, thereby decreasing the density and consequently improving the liquefiable soil layer by densification.

\section{Seismic risk management}

The FEM showed that the volume of soil activated during liquefaction dictates the deformations of the structure, which in turn can be controlled by the type and magnitude of stabilisation measures. Based on this, the authors propose the following framework for characterisation of seismic loading and resistance to liquefaction (Figures 13 and 14).

\section{Step 1: identification of the liquefiable layer}

The first step in a liquefaction assessment is to identify whether or not the soils are susceptible to liquefaction. The estimate

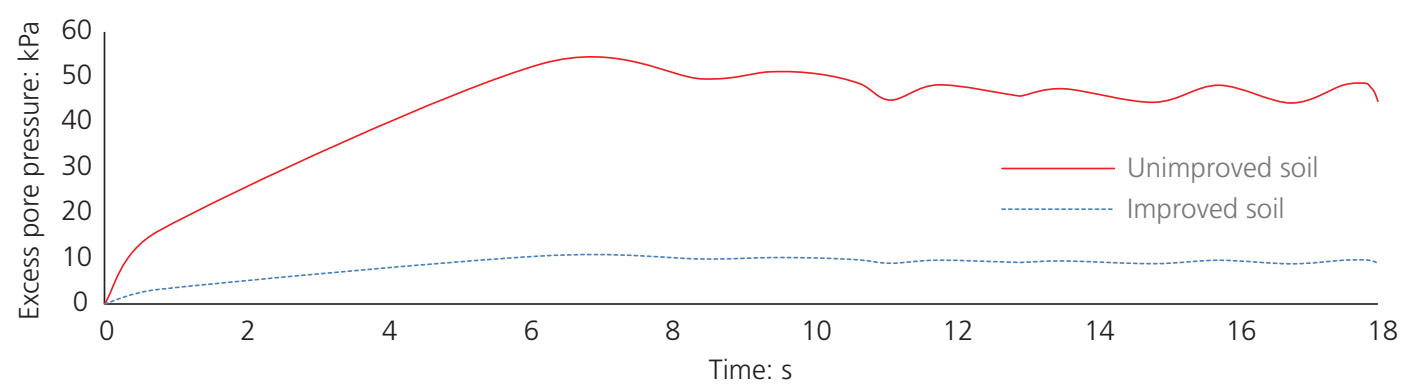

(a)

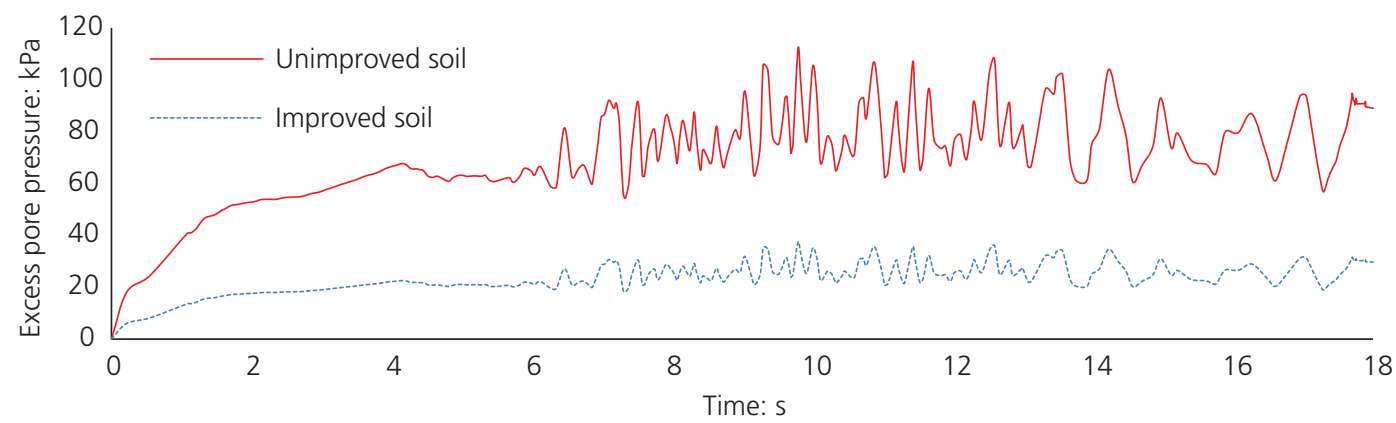

(b)

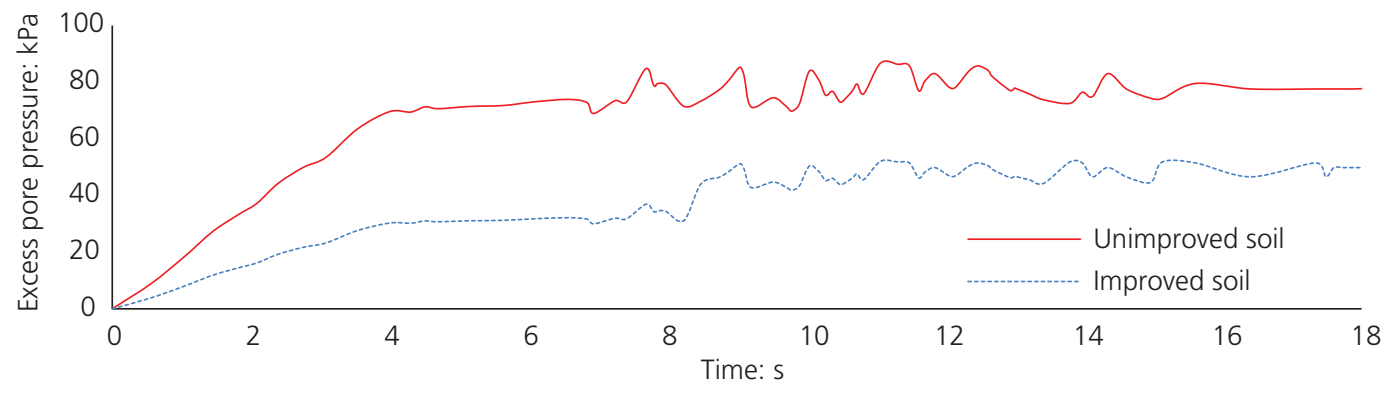

(c)

Figure 12. Excess pore water pressure generated near pile: (a) for $1 \mathrm{~m}$ cemented soil; (b) for $3 \mathrm{~m}$ lattice structure; (c) for $9 \mathrm{~m}$ lattice structure 


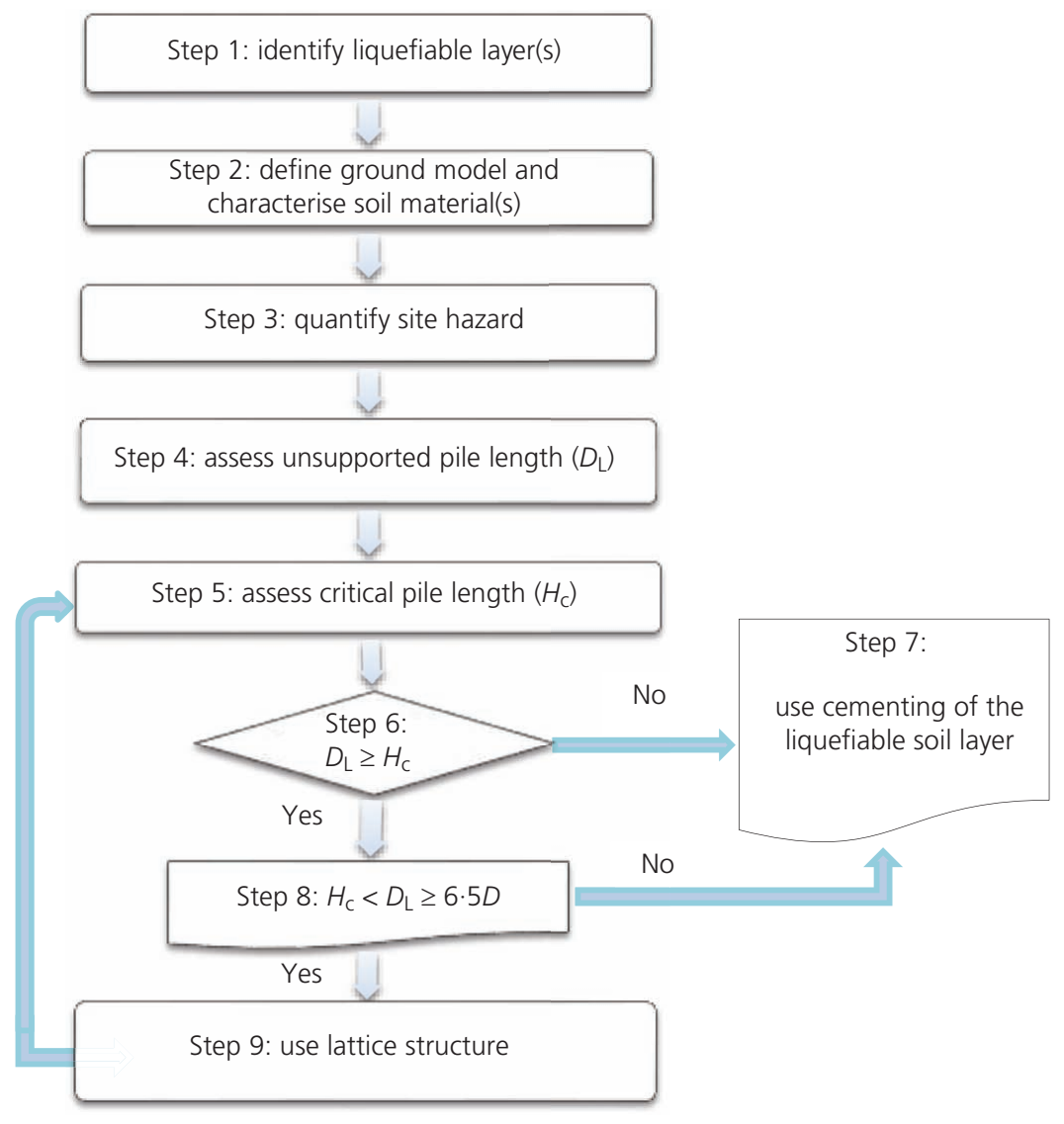

Figure 13. Seismic requalification methodology of a pile-supported structure. $D$, the diameter of pile; $D_{L}$, unsupported pile length; $H_{c}$, critical pile length in touch with liquefiable soil

of input ground motion at a site is a critical parameter in the characterisation of earthquake loading in conventional liquefaction potential analyses and can be obtained using the regional ground motion prediction equation (Goda and Atkinson, 2009, 2010; Goda and Hong, 2008). The liquefaction susceptibility can be preliminarily screened by using historical, geological, hydrological and compositional criteria (e.g. Kramer, 2008; Seed et al., 2003; Youd and Perkins, 1987), and the liquefaction potential can be defined using established methods (e.g. Idriss and Boulanger, 2008; Seed and Idriss, 1971, 1983, 1985).

\section{Step 2: characterisation of soil material}

The next step is to define local site conditions, including stratification, the engineering and material properties of different soil layers, possible groundwater conditions, the thickness and location of liquefiable soil and the length of pile in touch with the liquefied soil zone. In situ geotechnical tests, namely the cone penetration test and standard penetration test, are the empirical methods for evaluating liquefaction (Boulanger and Idriss, 2014; Cetin et al., 2002, 2004; Goda et al., 2011; Juang et al., 2005; Moss et al., 2006; Seed, 1979; Seed and Idriss, 1971, 1982; Seed et al., 1977, 1983; Stark and Olson, 1995). Laboratory testing of 'undisturbed samples', typically simple shear, triaxial or torsional cyclic tests, can be also used to derive the soil material properties (e.g. Boulanger and Idriss, 2005; Bray and Sancio, 2006; Seed et al., 2003). Some engineering properties in terms of seismic hazards can be derived from the national annexes of the relevant Eurocodes. For example, Eurocode 8 part 5 (BSI, 2005b) shows two separate empirical approaches for clean sand and silty sand which show liquefaction potential.

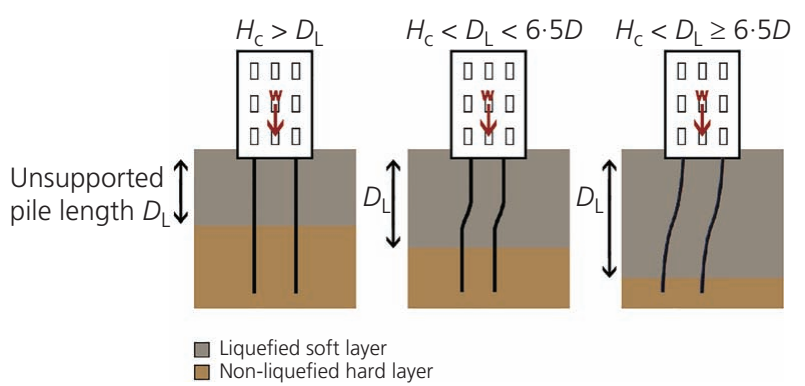

Figure 14. Concept of critical length of the pile and unsupported length of the pile (adapted from Bhattacharya and Goda (2013)) 


\section{Step 3: site hazard quantification}

After the soil materials have been identified and characterised, the site-specific ground response needs to be determined, the liquefaction hazard to be analysed and the as built details of structure and the response of infrastructure to be modelled in order to obtain the seismic effects for a particular site and structure (BSI, 2005a; Ghosh and Bhattacharya, 2008; Govindaraju and Bhattacharya, 2012).

\section{Step 4: assessment of unsupported pile length}

The next step is to estimate the laterally unsupported length of the pile $D_{\mathrm{L}}$ in the seismic event. This is based on the depth of liquefaction potential evaluation of a soil column and often can be obtained by using simplified stress-based methods (Greenfield, 2017; Idriss and Boulanger, 2008; Khoshnevisan et al., 2015; Kramer, 1996; Seed and Idriss, 1971; Youd et al., 2001). Indeed, $D_{\mathrm{L}}$ can be determined by using the thickness of liquefied soil layers plus some additional length necessary for fixity at the bottom of the liquefied soils (Bhattacharya and Goda, 2013). In this study, the criterion for determining the unsupported length $\left(D_{\mathrm{L}}\right)$ based on liquefied soil profile (the base case is set to a limiting thickness of non-liquefied soil layers for lateral support of a pile) equal to $6 \cdot 5 D$ was considered.

\section{Step 5: assessment of maximum critical pile length}

The critical pile length resisting buckling failure, $H_{\mathrm{c}}$, is a function of pile characteristics and pile head loading (Bhattacharya and Goda, 2013) which a pile can sustain without collapse due to combined axial and lateral loading. The critical pile length depends on the type and dimension of superstructure (bridge or building), bending stiffness, axial load acting on the pile, dynamic characteristics of superstructure and boundary conditions of the pile at the top and bottom of the liquefiable layer. $H_{\mathrm{c}}$ can be estimated using an established method (Bhattacharya and Goda, 2013)

$$
\text { 1. } H_{\mathrm{c}}=\sqrt{\frac{\emptyset \pi^{2} \mathrm{EI}}{K^{2} P_{\text {dynamic }}}}
$$

where EI is the bending stiffness of the pile, $K$ is the column effective length factor $\varnothing<1$; it is noted that, in reality, this factor depends on the axial load, imperfection of piles and residual stress in the pile due to driving. An estimate of the maximum axial compressive load acting on a pile can be given by

$$
\text { 2. } P_{\text {dynamic }}=(1+\alpha) P_{\text {Static }}
$$

where $\alpha$ is termed as the dynamic axial load factor and is a function of type of superstructure, height of the centre of mass of the superstructure and characteristics of the earthquake shaking (e.g. frequency content and amplitude).

In this study, the values of input parameters are set to $0 \cdot 35$, and $1 \cdot 0$ for $\varnothing$ and $K$, respectively.
Step 6: comparison of $H_{c}$ with $D_{L}$, potential failure

In this step, the critical pile length $\left(H_{\mathrm{c}}\right)$ that is in touch with liquefiable soil should be assessed in order to identify the appropriate method to retrofit the foundations to resist seismic loading. If $H_{\mathrm{c}} \geq D_{\mathrm{L}}$, most of the pile length will be in touch with liquefiable soil, the pile would be at risk of failure due to buckling and, thus, would require retrofitting.

\section{Step 7: cementation of the soil surrounding the pile within the liquefiable soil zone}

This step presents an appropriate method for pile-supported structures by using cementation of the soil surrounding the pile within the liquefiable zone. The cement injection technique (see the section headed 'Cement injection improvement') in stabilised soil may be sufficient to prevent triggering of liquefaction where the pile length in touch with the liquefiable soil is within $6 \cdot 5 D$ of the total pile length. The microjet grouting method can be used for the cementation. This method is characterised by its ability to produce soil improvement structures with arbitrary shapes and large diameter including walls, fans and lattices (Burke, 2004; Malinin et al., 2010; Stark et al., 2009; Stoel, 2001; Yamauchi et al., 2017). This construction method can be used near boundaries of existing structures, and the total construction cost, including economic damage, of grouting can be lower than the construction cost of conventional methods (Saurer et al., 2011; Stoel, 2001; Yamauchi et al., 2017; Yoshida, 2010).

\section{Step 8: identification of the remediation technique}

In this step, the critical pile length $\left(H_{\mathrm{c}}\right)$ that is in touch with liquefiable soil (estimated in step 6) should be compared with the length of the pile to identify an appropriate method to retrofit the foundations to resist seismic loading. Therefore, for $H_{\mathrm{c}}<D_{\mathrm{L}} \geq$ $6 \cdot 5 \mathrm{D}$, cement injection alone cannot be used for stabilisation.

\section{Step 9: use of lattice structure to mitigate the risk of buckling failure}

According to the analysis of the lattice structure mechanism (see the section headed 'Lattice improvement'), it can be seen that this mechanism is sufficient to prevent liquefaction triggering and ground improvement in liquefiable soil when cementation is not enough (i.e. when $\left.D_{\mathrm{L}} \geq 6 \cdot 5 \mathrm{D}\right)$. However, if the thickness of liquefied soil layer(s) is higher than the total pile length, it would be recommended to use both techniques.

A systematic evaluation has been carried out to develop this methodology on the basis of understanding of the potential for initiation of liquefaction, the mechanics of the liquefaction process, various aspects of pile failure and the feasibility of a successful remediation technique. Numerical analyses have developed the effects of liquefaction triggering on seismic response of structures and soil stiffness, and the results of analysis illustrated a robust framework for mitigation of pile foundations by using recent design earthquakes. This framework uses 3D nonlinear and effective analysis with few key parameters and presents 
more simple, effective and economically viable techniques than conventional frameworks.

\section{Conclusions}

The seismic risk of liquefaction was evaluated by comparing relevant mitigating measures against pile failure in liquefied soil. Numerical analyses of unimproved and stabilised soil models with cement injection and lattice structure techniques were performed to investigate their effects in liquefiable soil when subject to seismic loading. A reinforced-concrete pile constructed in a stratified soil system and carrying both axial and seismic earthquake loading was analysed for both cementation and lattice structure retrofit within the liquefiable soil zone. It was found that for the range of parameters used in this study, the bending moment reduction using cement injection in the liquefiable soil may be sufficient to prevent liquefaction triggering for thicknesses of up to one-third $(6 \cdot 5 D)$ of the length of the pile in touch with the liquefiable soil. For conditions other than these, it is recommended that the cement injection mechanism should be considered as a secondary rather than primary mechanism for ground improvement in liquefiable soil. The lattice structure technique, on the other hand, was found to reduce pore pressure effectively, even in the high thickness of liquefiable soil. This improvement was most likely achieved by wall failure being prevented and through lateral soil movements being restrained. However, in the higher thickness of liquefiable soil, the walls were flexible and so may improve by just $50 \%$. These were most likely due to lateral movements or densification of the sand beneath the shear wall. Thus, it is recommended that in these conditions it may be better to consider a combination of both techniques for ground improvement. Overall, it was found that both techniques are effective and economically viable to reduce or avoid potential structural damage caused by liquefied soil.

\section{REFERENCES}

Adalier K, Elgamal A, Meneses J and Baez Jl (2003) Stone columns as liquefaction counter-measure in non-plastic silty soils. Soil Dynamics and Earthquake Engineering 23(7): 571-584, https://doi.org/10.1016/ S0267-7261(03)00070-8.

Asgari A, Oliaei M and Bagheri M (2013) Numerical simulation of improvement of a liquefiable soil layer using stone column and pilepinning techniques. Soil Dynamics and Earthquake Engineering 51: 77-96, https://doi.org/10.1016/j.soildyn.2013.04.006.

Baez JI (1995) A Design Model for the Reduction of Soil Liquefaction by Using Vibro-stone Columns. PhD thesis, University of Southern California, Los Angeles, CA, USA.

Balakrishnan A and Kutter BL (1999) Settlement, sliding and liquefaction remediation of layered soil. Journal of Geotechnical and Geoenvironmental Engineering 125(11): 968-978, https://doi.org/10. 1061/(asce)1090-0241(1999)125.

Banerjee S and Shirole O (2014) Numerical analysis of piles under cyclic lateral load. Indian Geotechnical Journal 44(4): 436-448, https://doi. org/10.1007/s40098-013-0092-0.

Bhattacharya S (2006) Safety assessment of existing piled foundations in liquefiable soils against buckling instability. ISET Journal of Earthquake Technology 43(4): 133-147.

Bhattacharya S (2014) Safety assessment of piled buildings in liquefiable soils: mathematical tools. In Encyclopedia of Earthquake Engineering
(Beer M, Kougioumtzoglou IA, Patelli E and Au ISK (eds)). Springer, Berlin, Germany, https://doi.org/10.1007/978-3-642-36197-5_232-1.

Bhattacharya S and Goda K (2013) Probabilistic buckling analysis of axially loaded piles in liquefiable soils. Soil Dynamics and Earthquake Engineering 45: 13-24, https://doi.org/10.1016/j.soildyn.2012.10.004.

Bhattacharya S and Madabhushi SPG (2008) A critical review of methods for pile design in seismically liquefiable soils. Bulletin of Earthquake Engineering 6(3): 407-446, https://doi.org/10.1007/ s10518-008-9068-3.

Bhattacharya S, Madabhushi SPG and Bolton MD (2004) An alternative mechanism of pile failure in liquefiable deposits during earthquakes. Géotechnique 54(3): 203-213, https://doi.org/10.1680/geot.2004.54.3. 203.

Bhattacharya S, Hyodo M, Goda K, Tazoh T and Taylor C (2011) Liquefaction of soil in the Tokyo Bay area from the 2011 Tohoku (Japan) earthquake. Soil Dynamics and Earthquake Engineering 31(11): 1618-1628, https://doi.org/10.1016/j.soildyn. 2011.06.006.

Bhattacharya S, Tokimatsu K, Goda K et al. (2014) Collapse of Showa Bridge during 1964 Niigata earthquake: a quantitative reappraisal on the failure mechanisms. Soil Dynamics and Earthquake Engineering 65: 55-71, https://doi.org/10.1016/j.soildyn.2014.05.004.

Booth E (1994) Concrete Structures in Earthquake Regions, 1st edn. Longman Scientific, Harlow, UK.

Boulanger RW and Idriss IM (2005) Evaluating cyclic failure in silts and clays. Proceedings, Geotechnical Earthquake Engineering Satellite Conference on Performance Based Design in Earthquake Geotechnical Engineering: Concepts and Research, Tokyo, Japan, pp. 78-86.

Boulanger RW and Idriss IM (2014) CPT and SPT Based Liquefaction Triggering Procedures. Center for Geotechnical Modeling, University of California at Davis, Davis, CA, USA, Report No. UCD/CGM-14/0.

Bray JD and Sancio RB (2006) Assessment of the liquefaction susceptibility of fine-grained soils. Journal of Geotechnical and Geoenvironmental Engineering 132(9): 1165-1177, https://doi.org/10. 1061/(asce)1090-0241(2006)132.

Brennan AJ and Madabhushi SPG (2002) Effectiveness of vertical drains in mitigation of liquefaction. Soil Dynamics and Earthquake Engineering 22(9-12): 1059-1065, https://doi.org/10.1016/s0267-7261 (02)00131-8.

BSI (2005a) BS EN 1998-1:2004+A1:2013: Eurocode 8: Design of structures for earthquake resistance. General rules, seismic actions and rules for buildings. BSI, London, UK.

BSI (2005b) BS EN 1998-5:2004: Eurocode 8: Design of structures for earthquake resistance. Foundations, retaining structures and geotechnical aspects. BSI, London, UK.

Burke G (2004) Jet grouting systems: advantages and disadvantages. GeoSupport 2004: Innovation and Cooperation in the Geo-industry, Conference Proceedings, Orlando, FL, USA, January, pp. 875-886.

Cetin KO, Der Kiureghian A and Seed RB (2002) Probabilistic models for the initiation of soil liquefaction. Structural Safety 24: 67-82, https:// doi.org/10.1016/s0167-4730(02)00036-x.

Cetin KO, Seed RB, Der Kiureghian A et al. (2004) Standard penetration test-based probabilistic and deterministic assessment of seismic soil liquefaction potential. Journal of Geotechnical and Geoenvironmental Engineering 130(12): 1314-1340, https://doi.org/10.1061/(asce)10900241(2004)130:12(1314).

Charlie WA, Rwebyogo MFJ and Doehring DO (1992) Time-dependent cone penetration resistance due to blasting. Journal of Geotechnical Engineering 118(8): 1200-1215, https://doi.org/10.1061/(asce)07339410(1992)118.

Coelho PALF, Haigh SK, Madabhushi SPG and O'Brien TS (2007) Postearthquake behaviour of footings employing densification to mitigate liquefaction. Ground Improvement 11(1): 45-53, https://doi.org/10. 1680/grim.2007.11.1.45. 
Dammala PK, Bhattacharya S, Krishna AM, Kumar SS and Dasgupta K (2017) Scenario based seismic re-qualification of caisson supported major bridges - a case study of Saraighat Bridge. Soil Dynamics and Earthquake Engineering 100: 270-275, https://doi.org/10.1016/j. soildyn.2017.06.005.

Dash S, Bhattacharya S and Blakeborough A (2010) Bending buckling interaction as a failure mechanism of piles in liquefiable soils. Soil Dynamics and Earthquake Engineering 30: 32-39.

Dassault Systèmes Simulia (2012) Abaqus User's Manual - Standard Version 6.12. Dassault Systèmes Simulia, Johnston, RI, USA.

Elias V, Welsh J, Wareen J et al. (2006) Ground Improvement Methods: Reference Manual - Volume I. Federal Highway Administration, US Department of Transportation, Washington, DC, USA, NHI Course No. 13204.

Funahara H, Shibata K, Nagao T and Kobayashi H (2012) Centrifuge tests on liquefaction suppression effect of overburden pressure from shallow foundations. Proceedings of the 9th International Conference on Urban Earthquake Engineering and 4th Asia Conference on Earthquake Engineering, Tokyo Institute of Technology, Tokyo, Japan, 6-8 March, pp. 581-585.

Ghosh B and Bhattacharya S (2008) Selection of appropriate input motion for foundation design in seismic areas. Proceedings of the 14th World Conference on Earthquake Engineering, 12-17 October, Beijing, China.

Gniel J and Bouazza A (2009) Improvement of soft soils using geogrid encased stone columns. Geotextiles and Geomembranes 27(3): 167-175, https://doi.org/10.1016/j.geotexmem.2008.11.001.

Goda K and Atkinson GM (2009) Probabilistic characterization of spatially correlated response spectra for earthquakes in Japan. Bulletin of the Seismological Society of America 99(5): 3003-3020, https://doi. org/10.1785/0120090007.

Goda K and Atkinson GM (2010) Intra-event spatial correlation of ground-motion parameters using SK-net data. Bulletin of the Seismological Society of America 100(6): 3055-3067, https:/doi.org/ $10.1785 / 0120100031$

Goda K and Hong HP (2008) Spatial correlation of peak ground motions and response spectra. Bulletin of the Seismological Society of America 98(1): 354-365, https://doi.org/10.1785/0120070078.

Goda K, Atkinson GM, Hunter JA, Crow C and Motazedian D (2011) Probabilistic liquefaction hazard analysis for four Canadian cities. Bulletin of the Seismological Society of America 101(1): 190-201, https://doi.org/10.1785/0120100094.

Govindaraju L and Bhattacharya S (2012) Site-specific earthquake response study for hazard assessment in Kolkata city (India). Natural Hazards 61(3): 943-965, https://doi.org/10.1007/s11069-0119940-3.

Greenfield MW (2017) Effects of Long-Duration Motions on Liquefaction Hazards. PhD thesis, University of Washington, Seattle, WA, USA.

Helwany S (2007) Applied Soil Mechanics with ABAQUS Applications. Wiley, Toronto, ON, Canada.

Hetényi M (1946) Beams on Elastic Foundation: Theory with Applications in the Fields of Civil and Mechanical Engineering. University of Michigan Press, Ann Arbor, MI, USA.

Idriss IM and Boulanger RW (2008) Soil Liquefaction during Earthquakes. Earthquake Engineering Research Institute, Oakland, CA, USA, EERI Monograph 12

JRA (Japanese Road Association) (2002) Specification for Highway Bridges, Part V, Seismic Design. JRA, Tokyo, Japan.

Juang CH, Yang SH and Yuan H (2005) Model uncertainty of shear wave velocity-based method for liquefaction potential evaluation. Journal of Geotechnical and Geoenvironmental Engineering 131(10): 1274-1282, https://doi.org/doi:10.1061/(asce)1090-0241(2005)131:10 (1274).

Khoshnevisan S, Juang H, Zhou Y and Gong W (2015) Probabilistic assessment of liquefaction-induced lateral spreads using CPT -
Focusing on the 2010-2011 Canterbury earthquake sequence. Engineering Geology 192: 113-128, https://doi.org/10.1016/j.enggeo. 2015.04.001.

Kitazume M and Takahashi H (2010) Centrifuge model tests on effect of deep mixing wall spacing on liquefaction mitigation. Proceedings of the 7th International Conference on Urban Earthquake Engineering \& 5th International Conference on Earthquake Engineering, Tokyo Institute of Technology, Tokyo, Japan, pp. 473-478.

Kramer SL (1996) Geotechnical Earthquake Engineering. Prentice Hall, Upper Saddle River, NJ, USA.

Kramer SL (2008) Evaluation of Liquefaction Hazards in Washington State. Washington State Department of Transportation, Olympia, WA, USA, WSDOT Research Report WA-RD 668.1.

Kramer SL, Valdez C, Blanchette B and Baker JW (2014) Performancebased Design Factors for Pile Foundations. Washington State Department of Transportation, Olympia, WA, USA, WSDOT Research Report WA-RD 827.1.

Krishna AM, Bhattacharya S and Choudhury D (2014) Seismic requalification of geotechnical structures. Indian Geotechnical Journal 44(2): 113-118, https://doi.org/10.1007/s40098-014-0115-5.

Kutter BL, Gajan S, Manda KK and Balakrishnan A (2004) Effects of layer thickness and density on settlement and lateral spreading. Journal of Geotechnical and Geoenvironmental Engineering 130(6): 603-614, https://doi.org/10.1061/(asce)1090-0241(2004)130:6(603).

Lo SR, Zhang R and Mak J (2010) Geosynthetic-encased stone columns in soft clay: a numerical study. Geotextiles and Geomembranes 28(3): 292-302, https://doi.org/10.1016/j.geotexmem.2009.09.015.

Lombardi D and Bhattacharya S (2012) Liquefaction of soil in the EmiliaRomagna region after the 2012, Northern Italy earthquake sequence. Natural Hazards 73(3): 1749-1770, https://doi.org/10.1007/s11069014-1168-6.

Lombardi D and Bhattacharya S (2014) Modal analysis of pile-supported structures during seismic liquefaction. Earthquake Engineering \& Structural Dynamics 43(1): 119-138, https://doi.org/10.1002/eqe.2336.

Lombardi D and Bhattacharya S (2016) Evaluation of seismic performance of pile-supported models in liquefiable soils. Engineering \& Structural Dynamics 45(6): 1019-1038, https://doi.org/10.1002/eqe. 2716.

Malinin A, Gladkov I and Malinin D (2010) Experimental research of jetgrouting parameters in different soil conditions. In Deep Foundations and Excavation (Tonon F, Liu X and Wu W (eds)). American Society of Civil Engineers, Reston, VA, USA, pp. 49-54.

McGann CR, Arduino P and Helnwein PM (2012) Development of Simplified Analysis Procedure for Piles in Laterally Spreading Layered Soils. Pacific Earthquake Engineering Research Center, Richmond, CA, USA, PEER Report 2012/05.

Mitchell JK and Solymar ZV (1984) Time-dependent strength gain in freshly deposited or densified sand. Journal of Geotechnical Engineering 110(11): 1559-1576, https://doi.org/10.1061/(asce)07339410(1984)110:11(1559).

Mitchell JK (2008) Mitigation of liquefaction potential of silty sands. In From Research to Practice in Geotechnical Engineering (Laier JE, Crapps DK and Hussein MH (eds)). American Society of Civil Engineers, Reston, VA, USA, pp. 433-451.

Mitrani H and Madabhushi SPG (2013) Geomembrane containment walls for liquefaction remediation. Proceedings of the Institution of Civil Engineers - Ground Improvement 166(1): 9-20, https://doi.org/10. 1680/grim. 10.00035

Moss RES, Seed RB, Kayen RE et al. (2006) CPT-based probabilistic and deterministic assessment of in situ seismic soil liquefaction potential. Journal of Geotechnical and Geoenvironmental Engineering 132(8): 1032-1051, https://doi.org/10.1061/(asce)1090-0241(2006) 1328:(1032).

Namikawa T, Koseki J and Suzuki Y (2007) Finite element analysis of lattice-shaped ground improvement by cement mixing for liquefaction 
mitigation. Soils and Foundation 47(3): 559-576, https://doi.org/10. 3208/sandf.47.559.

NEHRP (National Earthquake Hazards Reduction Program) (2000) Commentary (Federal Emergency Management Agency, USA, 369) for Seismic Regulations for New Buildings and Other Structures. Building Seismic Safety Council, Washington, DC, USA.

NEHRP (2012) Soil-Structure Interaction for Building Structures. National Institute of Standards and Technology, Gaithersburg, MD, USA, NIST GCR 12-917-21.

Nguyen TV, Rayamajhi D, Boulanger RW et al. (2012) Effect of DSM grids on shear stress distribution in liquefiable soil. In GeoCongress 2012: State of the Art and Practice in Geotechnical Engineering (Hryciw RD, Athanasopoulos-Zekkos A and Yesiller N (eds)). American Society of Civil Engineers, Reston, VA, USA, pp. 1948-1957.

Nguyen TV, Rayamajhi D, Boulanger RW et al. (2013) Design of DSM grids for liquefaction remediation. Journal of Geotechnical and Geoenvironmental Engineering 139(11): 1923-1933.

Rahmani A and Pak A (2012) Dynamic behaviour of pile foundations under cyclic loading in liquefiable soils. Computers and Geotechnics 40: 114-126, https://doi.org/10.1016/j.compgeo.2011.09.002.

Rayamajhi D, Nguyen TV, Ashford SA et al. (2014) Numerical study of shear stress distribution for discrete columns in liquefiable soils. Journal of Geotechnical and Geoenvironmental Engineering 140(3): 04013034, https://doi.org/10.1061/(ASCE)GT.1943-5606.0000970.

Rayamajhi D, Tamura S, Khosravi M et al. (2015) Dynamic centrifuge tests to evaluate reinforcing mechanisms of soil-cement columns in liquefiable sand. Journal of Geotechnical and Geoenvironmental Engineering 141(6): 04015015, https://doi.org/10.1061/(ASCE)GT. 1943-5606.000129.

Rostami R, Bhattacharya S, Hytiris N and Giblin M (2017) Seismic analysis of pile in liquefiable soil and plastic hinge. Geotechnical Research 4(4): 203-213, https://doi.org/10.1680/jgere.17.00009.

Sarkar R, Bhattacharya S and Maheshwari BK (2014) Seismic requalification of pile foundations in liquefiable soils. Indian Geotechnical Journal 44(2): 183-195, https://doi.org/10.1007/s40098-014-0112-8.

Saurer E, Marcher T and Lesnik M (2011) Grid space optimization of jet grouting columns. In Proceedings of the 15th European Conference on Soil Mechanics and Geotechnical Engineering (Anagnostopoulos A, Pachakis M and Tsatsanifos C (eds)). IOS Press, Amsterdam, the Netherlands, vol. 2, pp. 1055-1060.

Seed HB (1979) Soil liquefaction and cyclic mobility evaluation for level ground during earthquakes. Journal of Geotechnical Engineering 105(2): 201-255.

Seed HB and Idriss IM (1971) Simplified procedure for evaluating soil liquefaction potential. Journal of the Soil Mechanics and Foundations Division 107(SM9): 1249-1274.

Seed HB and Idris IM (1982) Ground Motions and Soil Liquefaction during Earthquakes. Earthquake Engineering Research Institute, Oakland, CA, USA.
Seed HB, Mori K and Chan CK (1977) Influence of seismic history on liquefaction of sands. Journal of the Geotechnical Engineering Division 103(GT4): 257-270.

Seed HB, Idriss IM and Arango I (1983) Evaluation of liquefaction potential using field performance data. Journal of Geotechnical and Geoenvironmental Engineering 109(3): 458-482.

Seed HB, Tokimatsu K, Harder LF and Chung RM (1985) Influence of SPT procedures in soil liquefaction resistance evaluations. Journal of the Geotechnical Engineering Division 111(12): 1425-1445.

Seed RB, Cetin KO, Moss RES et al. (2003) Recent advances in soil liquefaction engineering: a unified and consistent framework. Proceedings of the 26th Annual ASCE Los Angeles Geotechnical Spring Seminar, 30 April, Long Beach, CA, USA, pp. 1-71.

Stark TD and Olson SM (1995) Liquefaction resistance using CPT and field case histories. Journal of Geotechnical Engineering 121(12): 856-869, https://doi.org/10.1061/(ASCE)0733-9410(1995)121:12 (856).

Stark TD, Axtell PJ, Lewis JR et al. (2009) Soil inclusions in jet grout columns. Deep Foundations Institute Journal 3(1): 44-55, https://doi. org/10.1179/dfi.2009.004

Stoel A (2001) Grouting for Pile Foundation Improvement. $\mathrm{PhD}$ thesis, University of Delft, Delft, the Netherlands.

Tang L, Cong S, Ling X, Lu J and Elgamal A (2015) Numerical study on ground improvement for liquefaction mitigation using stone columns encased with geosynthetics. Geotextiles and Geomembranes 43(2): 190-195, https://doi.org/10.1016/j.geotexmem.2014.11.011.

Tokimatsu K and Asaka Y (1998) Effects of liquefaction-induced ground displacements on pile performance in the 1995 Hyogoken-Nambu earthquake. Soils and Foundations 38(Special Issue): 163-177.

Tokimatsu K, Mizuno H and Kakurai M (1996) Building damage associated with geotechnical problems. Soils and Foundations 36(Special Issue): 219-234.

Yamauchi T, Tezuka H and Tsukamoto Y (2017) Development of rational soil liquefaction countermeasure consisting of lattice-shaped soil improvement by jet grouting for existing housing estates. In Geotechnical Hazards from Large Earthquakes and Heavy Rainfalls (Hazarika H, Kazama M and Lee W (eds)). Springer, Tokyo, Japan, pp. 49-59.

Yoshida H (2010) The progress of jet grouting in the last 10 years in Japanese market. Proceedings of the 35th Annual Conference on Deep Foundations 2010, Hollywood, CA, USA, pp. 157-167.

Youd TL and Perkins DM (1987) Mapping of liquefaction severity index. Journal of Geotechnical Engineering 113(11): 1374-1392.

Youd TL, Idriss IM, Andrus RD et al. (2001) Liquefaction resistance of soils: summary report from the 1996 NCEER and 1998 NCEER/ NSF workshops on evaluation of liquefaction resistance of soils. Journal of Geotechnical and Geoenvironmental Engineering 127(10): 817-833, https://doi.org/10.1061/(ASCE)1090-0241(2001)127:10 (817).

\section{How can you contribute?}

To discuss this paper, please submit up to 500 words to the editor at journals@ice.org.uk. Your contribution will be forwarded to the author(s) for a reply and, if considered appropriate by the editorial board, it will be published as a discussion in a future issue of the journal. 